\title{
Readiness for ICT Based B2C Information Flow - Case Study of the Hungarian Food Sector
}

Szilvia Botos, Róbert Szilágyi, János Felföldi, Mihály Tóth

Institute of Applied Informatics and Logistics, Faculty of Economics and Business, University of Debrecen, Hungary

\begin{abstract}
The complexity of information flow and cooperation among enterprises operating in a supply chain is growing. This process has a significant impact on the economy and the objective is that both traditional and new ICT (Information and Communication Technology) solutions meet the pressing needs for more efficient business processes. The current paper focuses on enterprises belonging to the food supply chain and analyses some indicators supporting the information flow within the company and with partners (being either a partner enterprise or the final consumer). Our Institute has prepared a survey to examine the ICT usage and attitude by enterprises operating in the agri-food sector. The importance of business processes supportable by ICT had to be assessed by companies. In this study we evaluated the importance of some ICT indicators supporting information flow in the chain. The main objective of the current article is to determine the difference between food enterprises divided by different grouping factors regarding their evaluation of the chosen indicators. In our opinion, competitive advantage may be reached using ICT solutions for widening and maintaining relations through a more effective information flow with partners and consumers.
\end{abstract}

\section{Keywords}

Food sector, information flow, ICT, readiness, B2C.

Botos, S., Szilágyi, R., Felföldi, J. and Tóth, M. (2020) "Readiness for ICT Based B2C Information Flow - Case Study of the Hungarian Food Sector", AGRIS on-line Papers in Economics and Informatics, Vol. 12, No. 2, pp. 41-51. ISSN 1804-1930. DOI 10.7160/aol.2020.120204.

\section{Introduction}

Over the last two decades, many empirical and case studies have been published on the advantages that information systems may offer in decentralized supply chains. For this study, we first made a network analysis of literature to highlight those keywords and research topics that are mainly in connection with our research topic. Figure 1. provides information on those research topics that are in close connection with the food sector and ICT.

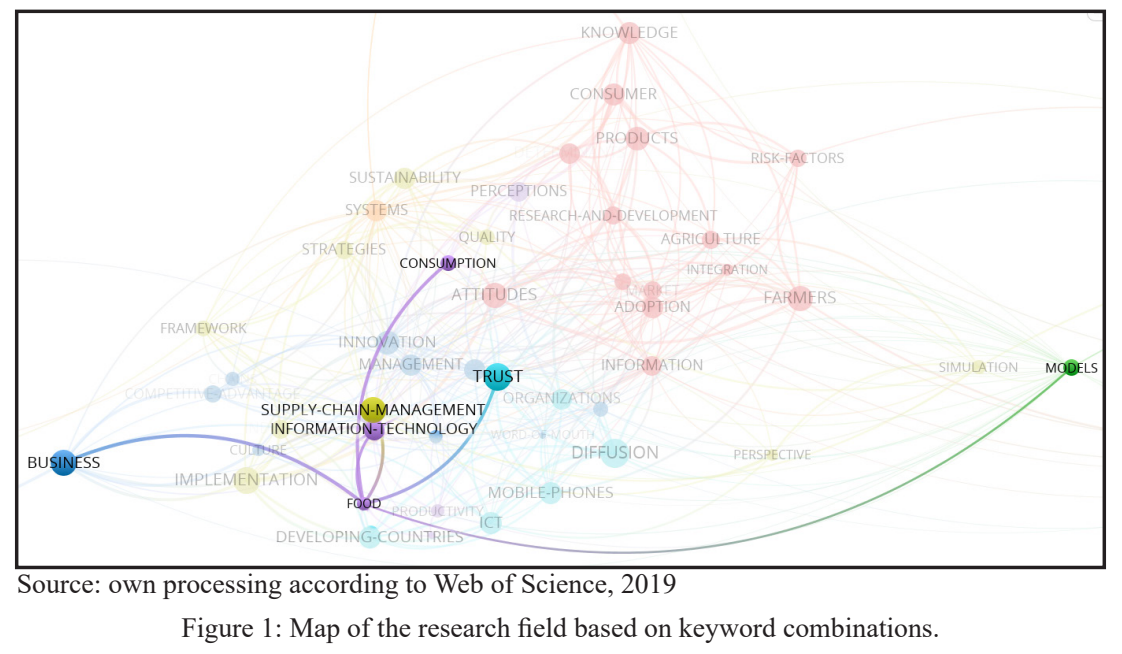


The main keyword connections with the keyword 'FOOD' are highlighted on the figure. This means that the analyses on food are considered a major research topic together with supply chain management, information technology, trust, consumption, business and models.

Regarding supply chains, arguments in favor of using information systems, advantages of informationsharing methods and impacts of the level of ICT usage are described both in synthesizing papers (Chen, 2003; Consoli, 2012; Viet et al., 2018) and empirical studies (Wu and Jia, 2018; Costantino et al., 2015). Good practices are also proposed in many papers and there are several case studies on this research field that analyse the information flow between different parts of the supply chain (Bian et al., 2016; Dominguez et al., 2018). Several models carried out and published in articles confirming the role of data collection and the importance of cooperation and information sharing among chain members (Fiala, 2005; Kirilova and Vaklieva-Bancheva, 2017).

In this paper we analyse the agri-food supply chain (comprising enterprises operating in agriculture or food manufacturing). Similar to any other sectors, SMEs have a key role; $99 \%$ of the enterprises belongs to this size category and they have a considerable share in indicators representing the agri-food sector (Felföldi et al., 2017). However, agri-food SMEs operate in an adverse economic environment compared to large companies (e.g., productivity, bargaining power, partnerships or the volume of marketable production). Regarding the usage of ICT, proving traceability and transparency is one of the main application fields in the agri-food sector. The role of traceability practices supported by ICT has been identified as a factor increasing food safety and quality in many empirical papers (Füzesi et al., 2016a; Maloni and Brown, 2006; Grimm et al., 2014; Dabenne and Gay, 2011; Ding et al., 2019; Bourlakis et al., 2014), however, ICT devices used for traceability purposes could provide information for the management too and it may be relevant for smoothing material flow and maintaining the continuity of information flow throughout the chain (Füzesi et al., 2016b), including consumers. ICT solutions have to be classified as one of the five criteria of transparency of food supply chain (Trienekens et al., 2012) and a more intensive deployment of ICT is founded to need not only for optimization of the company's internal processes but also for the successful involvement in e-business (Ahmedova, 2015). The increase of information transparency requires an infrastructure that proves a continuous information flow and data share with partners (Pant et al., 2015).

But besides advantages, implementation of an information system or a supply chain practice has to be financially sound for enterprises (Zhou et al., 2014) and company size seems to be a hindering factor. There is a sound literature due to the costs of ICT implementation (Tarute and Gatautis, 2014; Plumb and Zamfir, 2008; Modimogale and Kroeze, 2011). As large companies are moving to exploit the advantages offered by ICT, smaller companies face difficulties (European Commission, 2018). Stimulating the agri-food SMEs is important for both EU and national strategies. The eFoodChain project, provided by the European Commission, is one of the measures demonstrating the real benefits of ICT and eBusiness solutions for agri-food companies operating in the cereals, fresh fruits and vegetables and dairy sectors (FAO, 2016).

Today, open-source and free cloud services also can offer good solutions to overcome the reasons against using ICT. Látecková et al. (2018) confirm that the use of new ICT solutions could make agricultural enterprises more efficient and strengthen their competitive positions. ICT and innovation, as dynamic capabilities, are strategic resources that support to maintain a sustainable competitive advantage (Yunis, 2018). Cloud computing is an attractive option for many SMEs and several case studies from different countries reinforce the advantages (flexible cost structure, scalability, privacy and usage features) the technology could bring for SMEs (Sultan, 2011; Gupta et al., 2013; Tutunea, 2014; Vasiljeva et al., 2017). Open-source software and content management systems are broadly used in areas such as agriculture or rural development (Masner et al., 2018). Although, the relative advantages of these technologies can only be achieved if adequate resources are allocated (Hassan, 2017). Knowledge Management could also be a tool to contribute to an adequate level of supply chain information flow and SMEs could further increase the impact of it by better exploiting the opportunity offered by the new ICTs (Cerchione and Esposito, 2017.

Overall, there is a vast amount of literature on ICT characteristics in the context of the food supply chain, agri-food sector and SMEs, however, there is still a further need for analyses. In part because enterprises, in many cases, underestimate the potential offered by ICT, or cannot exploit them (Fawcett et al., 2011). In part, because there 
is still a shortage of empirical and case studies to substantiate advantages (Teunter et al., 2018). In 'Results and discussion' we show our analysis on some ICT indicators that can support information flow from business to consumer (B2C) in the case of food-producing and food processing companies. In 'Conclusions' we present some opportunities to an advanced B2C connection and future research directions.

\section{Materials and methods}

Our institute of the University of Debrecen prepared a questionnaire to survey the ICT usage characteristics of enterprises operating in the agrifood supply chain. Data of our survey analysed in current paper was collected in the fourth quarter of 2017. Respondents were Hungarian enterprises operating in sectors related to agriculture (producers) and the food industry (processors). The questionnaire was structured, responses were recorded by a market research company contacting the leaders or a management member of the enterprises. The sample has been selected by stratified sampling based on statistics of the Hungarian Central Statistical Office (HCSO). A total of 500 questionnaires were recruited for this study. The exact codes of the sample enterprises included in our research can be seen in Table 1 .

\begin{tabular}{l}
\hline A - Agriculture, forestry and fishing \\
\begin{tabular}{|l|}
01.11 - Growing of cereals (except rice), leguminous crops \\
and oil seeds
\end{tabular} \\
\hline 01.13 - Growing of vegetables and melons, roots and tubers \\
\hline 01.21 - Growing of grapes \\
\hline 01.24 - Growing of pome fruits and stone fruits \\
\hline 01.41 - Raising of dairy cattle \\
\hline 01.46 - Raising of swine/pigs \\
\hline 01.47 - Raising of poultry \\
\hline C - Manufacturing \\
\hline $\begin{array}{l}10.1 \text { - Processing and preserving of meat and production } \\
\text { of meat products }\end{array}$ \\
\hline 10.3 - Processing and preserving of fruit and vegetables \\
\hline 10.5 - Manufacture of dairy products \\
\hline 10.7 - Manufacture of bakery and farinaceous products \\
\hline Source: Eurostat, 2008 \\
Table 1. NACE Rev.2 Codes of Respondent Enterprises.
\end{tabular}

The number and share of enterprises in the sample database were compared, by sector, to the number of the whole population obtained from the database of Hungarian Central Statistical Office (HCSO), and the result can be seen in Table 2 .

The sample size was compared to the total population by size categories and the regions of Hungary and it shows a similar distribution; thus, the sample can be considered representative.

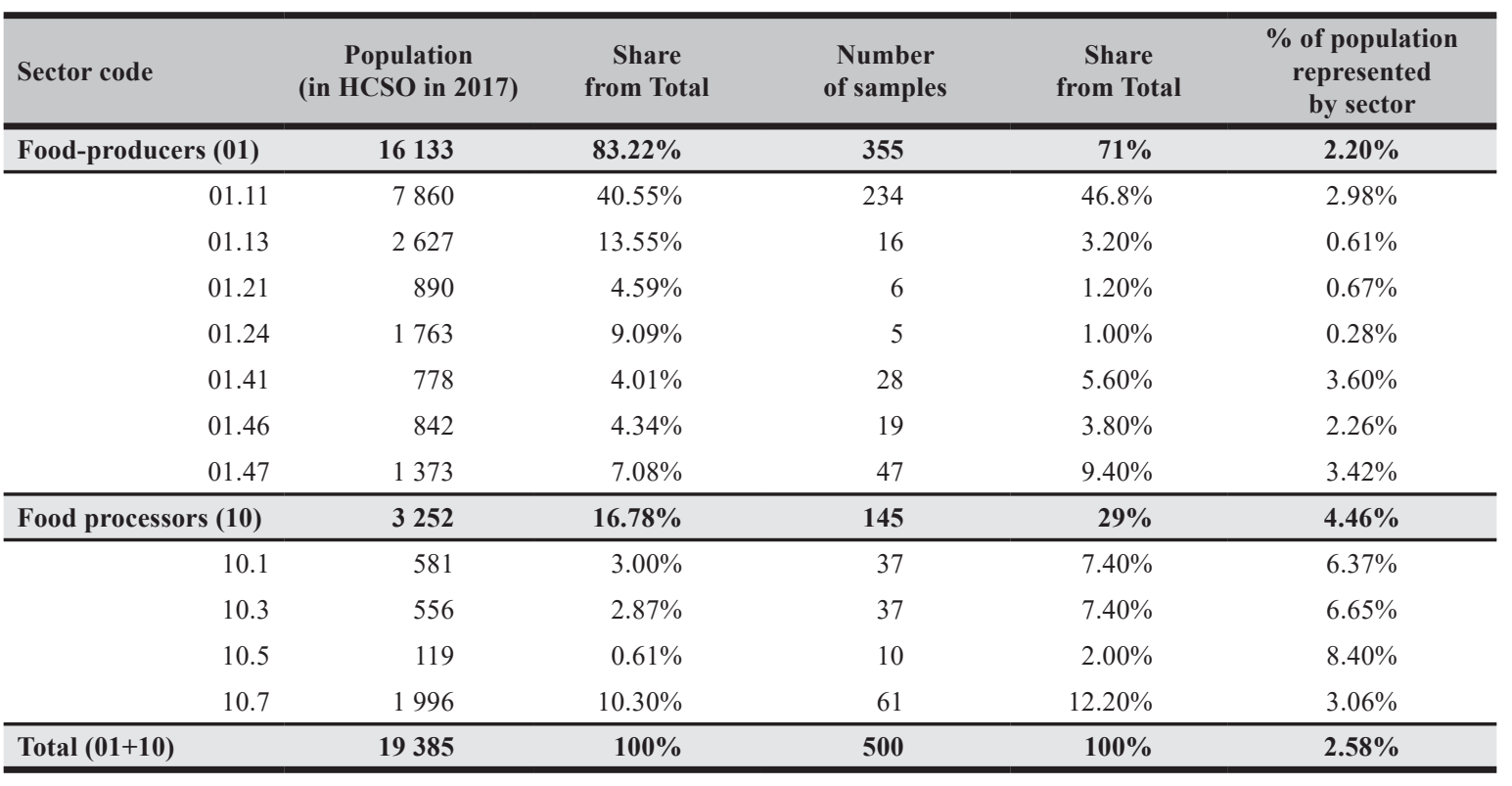

Source: own survey, 2017; HCSO database, 2017

Table 2: Share of respondent enterprises by sector. 
In this study, we evaluated three questions due to the relevance of information flow from business to consumer:

- Evaluate the importance of ICT solutions for marketing activities (Variable 1)

- Evaluate the importance of regular update of website information (Variable 2)

- Chose the technology that your company use for product identification

Descriptive Statistics, Ordinal Logistic Regression and Two-sample t-test were used to analyse our data and the software package used was R statistics and Microsoft Excel.

Respondents assessed Variable 1 and 2 on 5-point Likert scale; thus Ordinal Logistic Regression was used to determine the probability for Likert values of respondents grouped by different economic factors. Ordinal Logistic Regression is an extension of binomial logistic regression. This methodology is used to predict the dependent variable with ordered multiple categories and independent variables. In our case, dependent variables were indicators assessed on a Likert scale from 1 (not important) to 5 (very important) and independent variables were the grouping factors, such as main food sectors (producer or processor), size categories (small, medium or large). The model calculated the significance of coefficients and intercepts and since the p-value was $<0.05$ for all variables, they are statistically significant at a $95 \%$ confidence interval.

To determine whether there is a significant difference in the importance of ICT for business activities between sample groups clustered by food sectors we used two-sample t-test too. Our data sets contain two independent data sample and before comparing sample means, an F-test was used first if the standard deviations of the two populations are equal. We chose the F-test instead of the Levenetest as the latter is strongly significant for large and equal sample size. Our sample sizes are smaller and not equal; thus F-test was used and in output tables showing the results of two-sample t-tests also report the result of the F-test. To determine the difference between score means Two-sample t-test was used assuming equal and unequal variances on our Likert-scale data (Norman, 2010), based on the results of the F-test. The difference is considered significant if Sig. (2-tailed) $<0,05$.

\section{Results and discussion}

Information flow is crucial between partners in the supply chain and we consider cooperation and contact with final consumers would be important too, from both the point of view of foodproducers and food processors. In recent years, there is an increasing demand for information on food products. Information on the packaging, however, is not only to respond for the customer demand, but the advantage for them is also considerable and their choice could be more conscious. In this chapter we show our results on the importance of some ICT indicators which means a general measure in ICT development and which could support this aim. Ordinal logistic regression was used to calculate the probability that a given type of enterprise will recognize an ICT solution important or not.

First, we calculated the probability values for food-producers and food-processors separately. Our aim was to determine whether any difference between enterprises operating in a different stage of the food supply chain. Table 3 lists the mean scores for the two variables.

\begin{tabular}{rcc}
\hline & Variable 1 & Variable 2 \\
\hline $\begin{array}{r}\text { Food-producers } \\
(\mathrm{n}=355)\end{array}$ & 3.18 & 3.00 \\
\hline $\begin{array}{r}\text { Food processors } \\
(\mathrm{n}=145)\end{array}$ & 3.53 & 3.38 \\
\hline
\end{tabular}

Source: own survey, 2017

Table 3: Mean scores of variables by main food sectors.

We note from Table 1 that food processors have a higher mean score for both variables. Figure 2 shows the probability of what score would be given by companies operating in the food production and food processing sector on a 5-point Likert scale for the two analysed variables.

Our results show that the probability that a food processing company will consider ICT for marketing activities 'moderately important' or 'very important' is a bit higher than $58 \%$, while this value is slightly slower than $45 \%$ in the case of food producers. The result is similar in the case of the importance of continuous and regular update of information on website, the probability for 'important' or 'very important' is $\sim 56 \%$ for food processors and only $\sim 45 \%$ or producers.

Further analyses were done by size categories and processing subsectors.

The sample size enables us to apply two-sample t-test to determine whether the difference between food-producers and food processors is significant. Table 4 details the descriptive statistics of the two variables. 


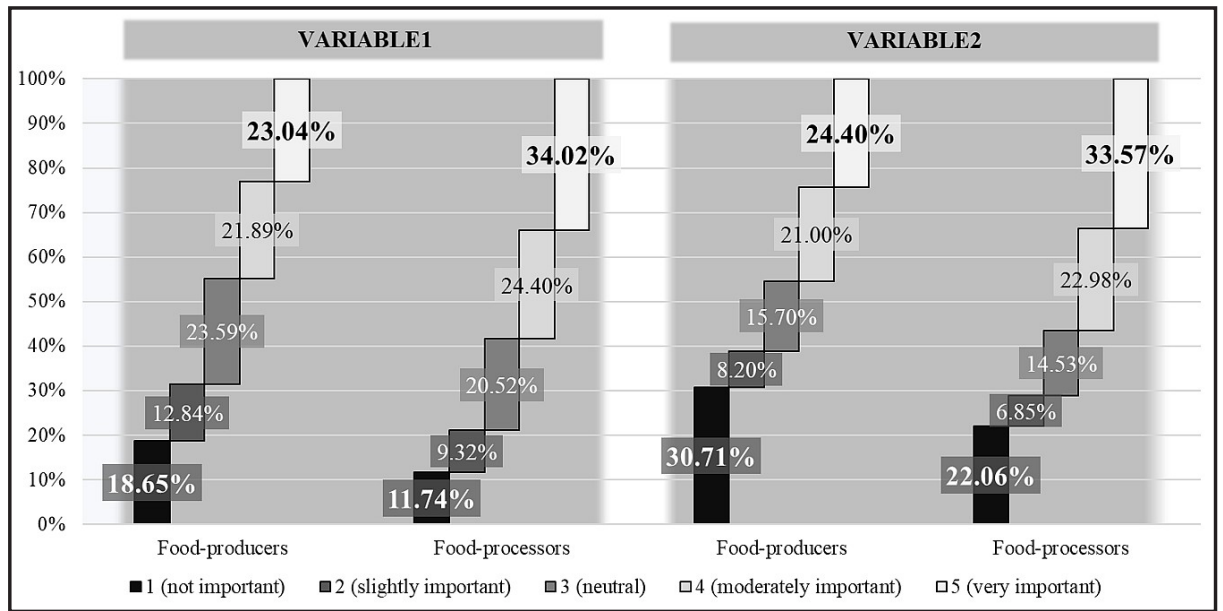

Source: own survey, 2017

Figure 2: Forecast values for the variables by respondent enterprises.

\begin{tabular}{|c|c|c|c|c|c|c|}
\hline \multirow{2}{*}{ Variables } & \multicolumn{3}{|c|}{ "Food producers Observations: 355" } & \multicolumn{3}{|c|}{ "Food processors Observations: 145" } \\
\hline & Mean & Std.Deviation & Std.Error Mean & Mean & Std.Deviation & Std.Error Mean \\
\hline $\begin{array}{l}\text { Importance of ICT for marketing } \\
\text { activities }\end{array}$ & 3.1887 & 1.3491 & 0.0716 & 3.5310 & 1.5140 & 0.1257 \\
\hline $\begin{array}{l}\text { Importance of continuous } \\
\text { and regular update of information } \\
\text { on website }\end{array}$ & 3.0028 & 1.5793 & 0.0838 & 3.3862 & 1.5509 & 0.1288 \\
\hline
\end{tabular}

Source: own survey, 2017

Table 4: Group statistics of the scores given by food producers and food processors.

\begin{tabular}{|c|c|c|c|c|c|c|c|c|c|c|}
\hline \multirow[b]{2}{*}{ Variables } & \multicolumn{3}{|c|}{ F-test for Equality of Variances } & \multicolumn{7}{|c|}{ Two sample t-test for Equality of Means } \\
\hline & $\mathbf{F}$ & $\begin{array}{l}\text { "Sig. } \\
\text { (2P)" }\end{array}$ & F-crit & t & df & $\begin{array}{c}\text { "Sig. } \\
\text { (2-tailed)" }\end{array}$ & $\begin{array}{c}\text { Mean } \\
\text { difference }\end{array}$ & $\begin{array}{l}\text { Std. Error } \\
\text { Difference }\end{array}$ & \multicolumn{2}{|c|}{$\begin{array}{l}95 \% \text { Confidence Interval } \\
\text { of the Difference }\end{array}$} \\
\hline $\begin{array}{l}\text { Importance of ICT } \\
\text { for marketing activities }\end{array}$ & 0.7940 & 0.0903 & 0.7992 & -2.4828 & 498 & 0.0133 & -0.3423 & 0.1378 & -0.6132 & -0.0714 \\
\hline $\begin{array}{l}\text { Importance of continuous } \\
\text { and regular update } \\
\text { of information on website }\end{array}$ & 1.037 & 0.8109 & 1.2675 & -2.4759 & 498 & 0.0136 & -0.3833 & 0.1548 & -0.6876 & -0.0791 \\
\hline
\end{tabular}

Source: own survey, 2017

Table 5: Output Table of Two Sample T-test.

Variable means are higher in both cases for food processors; however, these means are all under 4. This means that enterprises do not consider important these basic ICT-based services to make the opportunity for a more effective information flow. The difference is approximately 0.4 for both variables and Table 5 lists the result of the twosample t-test.

The results suggest that there is a significant difference between producers and processors in food sector. The mean scores given by food processors were significantly higher both for the importance of ICT for marketing activities (Sig. (2-tailed) $=0.0134$ and t-value $=$ -2.4829) and for the importance of continuous and regular update of information on website
(Sig. $(2$-tailed $)=0.0136$ and $\mathrm{t}$-value $=-2.4759)$. In fact, the food processing sector is closer for consumers as these companies have more data on food products, but our result still indicates a willingness to a more effective cooperation within the supply chain. As manufacturing companies can share information on labels and packages, a higher evaluation of these ICT opportunities suggests a tendency to provide easy access to information and to have an impact on consumer choice. Foodproducers produce mainly raw food materials, but they could also participate in information flow in the chain. Producing companies can also use an online platform for sharing indicators that consumers are interested in. 


\section{Difference by sector and size category}

Within sectors, we considered an important issue with measuring differences by size categories. Revealing the relative positions of size categories (micro, small, medium and large) regarding the ICT usage and tendency of adoption could be useful for both policy makers and company owners. Mean scores of the importance of ICT solutions in marketing activity (Variable 1) and the importance of Regular update of website information (Variable 2) are presented first by size categories in the production and processing part of the supply chain. Large category is excluded from this analyse for the small sample size $(n=8)$. Table 6 lists the score means.

Mean scores of food processing companies clearly exceed the mean values of food-producers. Regarding the size categories, values of mediumsized companies are higher in three cases. Figure 3 demonstrates the result of the logistic regression and shows the probabilities for evaluating variables important or not.

Figure 3 shows a clear growing trend between size categories; the larger the size of a company, the higher the percentage considering a variable 'very important'.
We analysed the situation of companies separately by NACE Rev. 2 codes; our aim was to determine the impact of activities on ICT evaluation. Due to the size of food-producing companies, this analysis was made only for food processing activities. The score means of variables calculated by food processing activities can be seen in Table 7 .

\begin{tabular}{lcc}
\hline & Variable 1 & Variable 2 \\
\hline $\begin{array}{l}\text { Processing and preserving of meat } \\
\text { and production of meat products }\end{array}$ & 3.57 & 3.57 \\
\hline $\begin{array}{l}\text { Manufacture of dairy products } \\
\text { Processing and preserving of fruit } \\
\text { and vegetables }\end{array}$ & 3.70 & 2.40 \\
\hline $\begin{array}{l}\text { Manufacture of bakery and farinaceous } \\
\text { products }\end{array}$ & 3.57 & 3.49 \\
\hline
\end{tabular}

Source: own survey, 2017

Table 7: Mean score of variables by the processing sector.

There are only minor differences between score means by activities; however, in the case of dairy manufacturing the mean score is significantly lower than the others. Figure 4 shows the percentages for probabilities by food processing sectors.

The probability for evaluating the variables at least 4 (moderately important) is much higher when the sample is grouped by activities. For Variable 1,

\begin{tabular}{lccccccc}
\hline & & Variable 1 & & \multicolumn{3}{c}{ Variable 2 } \\
& Micro & Small & Medium & Micro & Small & Medium \\
\hline Food-producers & 3.09 & 3.26 & 4.07 & 3.06 & 2.88 & 3.14 \\
Food processors & 3.14 & 3.53 & 3.19 & 3.27 & 3.21 & 3.85 \\
\hline
\end{tabular}

Source: own survey, 2017

Table 6: Mean scores of variables by main food sectors and size categories.

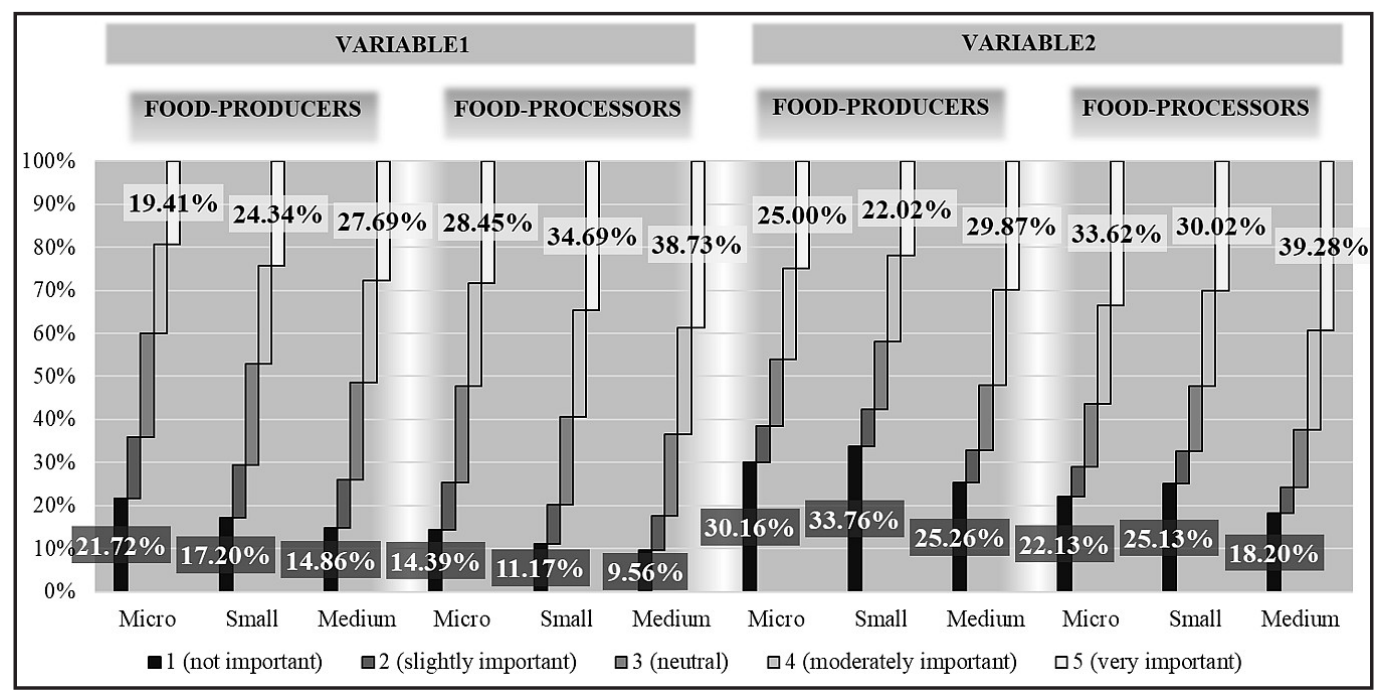

Source: own survey, 2017

Figure 3: Forecast values for the variables by main food sectors and size categories. 


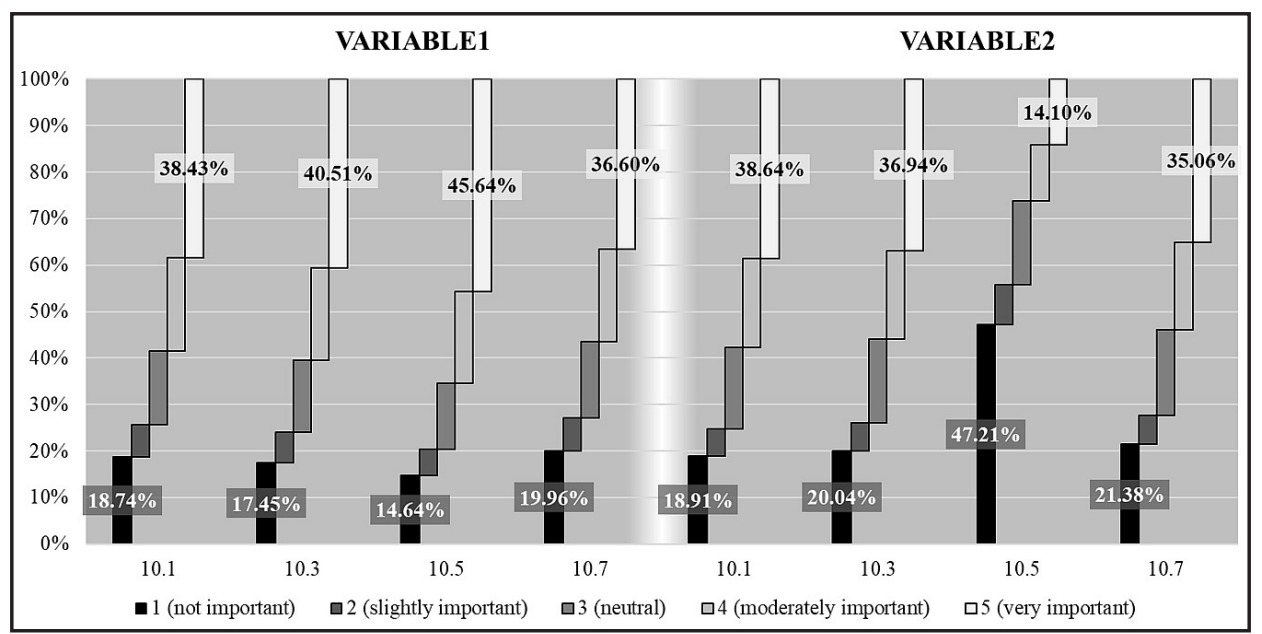

Source: own survey, 2017

Figure 4: Forecast values for the variables by food processing sectors.

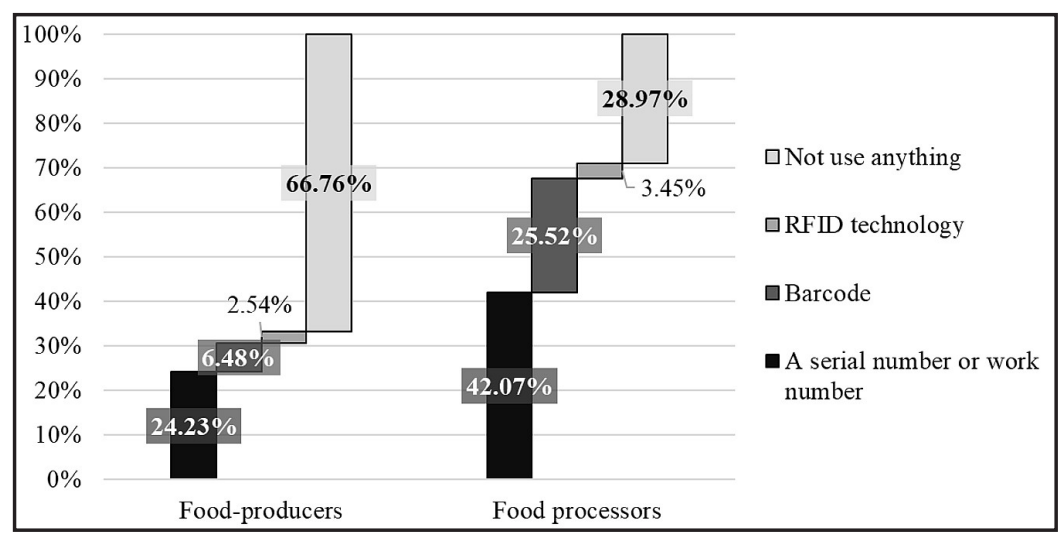

Source: own survey, 2017

Figure 5: Share of respondent enterprises by sector and product identification technology.

the chance of an evaluation under 4 is less than $40 \%$ in almost all cases. For Variable 2, this probability is a little bit higher; furthermore, the chance for assessing it to 1 (not important) is extremely high. We assume that the dairy sector is concentrated and online appearance is much less important for them because there is an already established up- and downstream cooperation within the sector.

Finally, we present here the share of applying different product identification technologies as we consider important these technologies to create an 'information handover point' between companies and consumers. Regarding information flow, our research targeted mainly the tools supportable by ICT which can help data and information exchange between partners and consumers. Product identification technology may be used in order to easy and effective information transfer towards consumers. Figure 5 shows the share of the most widely used technologies.
In the case of food-producers, the application of a serial or work number has the highest proportion $(24 \%)$. This type of identification is widely used in the processing sector as well (42\% of the respondent enterprises); furthermore, the barcode also has a high ratio $(25.5 \%)$. These codes could be used for applications on the consumer side for displaying information on the products. By a digitalized way and using a collaboration of the ICT-based information platforms, consumers could access all the information they need easily and immediately, even for the moment when they choose a product. Providing the opportunity for consumers using these technologies may support them in conscious food consumption. 


\section{Conclusion}

The current paper is a pre-study for analysing the readiness of enterprises operating in the food sector for an appropriate level information flow with partners and mainly consumers. We analysed the opinions on the importance of two variables: ICT for marketing activities (Variable 1) and the continuous and regular update of information on website (Variable 2). The grouping factors were the main food sectors (producing and processing), food processing subsectors and enterprise size categories. Our result from ordinal logistic regression suggests that food processors are ahead of food producers in the importance of online contact. Probability values for the variables are considered 'very important' or 'moderately important' were higher with 13 and $11 \%$, respectively, in the favour of food processors. Two-sample t-test showed that the assessment given by food processors is significantly higher ( $\mathrm{Sig}$. (2-tailed) $<0,05$ ) for both variables compared to food-producers. The t-values for Variable1 and Variable 2 were -2.4829 and -2.4759 , respectively. Our experiments are in line with those results claiming that applying ICT solutions supporting different business activities is generally driven by larger companies. Our analyse by enterprise size categories (micro, small and medium) showed a clear growing trend; the larger the size of a company, the higher the percentage considering a variable 'very important'. The average difference between micro and medium-sized companies was between 5 and $10 \%$. Larger companies assess an ICT solution important with a greater probability than smaller enterprises. However, this process may also promote smaller enterprises and agricultural farms to improve the level of ICT infrastructure and usage.

In our opinion, a dedicated strategy supporting the ICT development of smaller enterprises is required. Regarding SMEs, several studies have been published. There is a need for support by policy makers in prioritizing small farms, forming a national agricultural strategy and creating an RDP support structure (Veveris et al., 2019). At the policy level, a high priority should be given to advancing ICT skills, especially for the human capital of SMEs (Giotopoulos et al., 2017). Analyses on the business activities supportable by ICT can contribute to a more effective information share and this could lead to more conscious food purchasing decisions at the end of the supply chain. Information display is also an important issue as a complementary service for consumers. Papers analysing food information that consumers are interested in means a good starting point for an effective information flow. For instance, Kubicová et al. (2019) analysed the dairy sector and they determine great importance on factors that could be appeared digitalized. Further data collection on the requirements from the consumer side will be our following research direction.

We believe that providing advanced information service for food consumers would be an advantage for companies, including SMEs. Taking into account their financial situation, cloud services, applications for smartphones and using currently available technologies (e.g., barcodes, websites, marketing opportunities) mean a cost-effective option for them. Our suggestion aims mainly for SMEs as ICT adoption is crucial for them. ICT solutions are widely used for different business activities and enterprises can reach a competitive advantage by applying them. In our view, ICT based information flow has a positive effect throughout the food supply chain and the connection between agri-food companies and the consumer could increase customer satisfaction through an informed choice and more conscious purchasing.

\section{Acknowledgments}

The work/publication is supported by the EFOP3.6.1-16-2016-00022 project. The project is co-financed by the European Union and the European Social Fund.

\section{Corresponding authors \\ Dr. Szilvia Botos}

Institute of Applied Informatics and Logistics, Faculty of Economics and Business

University of Debrecen, Böszörményi út 138, H-4032 Debrecen, Hungary

E-mail: botos.szilvia@econ.unideb.hu 


\section{References}

[1] Ahmedova, S. (2015) "Factors for Increasing the Competitiveness of Small and MediumSized Enterprises (SMEs) in Bulgaria”, Procedia - Social and Behavioral Sciences, Vol. 195, pp. 1104-1112. ISSN 1877-0428. DOI 10.1016/j.sbspro.2015.06.155.

[2] Bian, W., Shang, J. and Zhang, J. (2016) "Two-Way Information Sharing Under Supply Chain Competition", International Journal of Production Economics, Vol. 178, pp. 82-94. ISSN 0925-5273, E-ISSN 1873-7579. DOI 10.1016/j.ijpe.2016.04.025.

[3] Bourlakis, M., Maglaras, G., Gallear, D. and Fotopoulos, C. (2014) "Examining Sustainability Performance in the Supply Chain: The Case of the Greek Dairy Sector", Industrial Marketing Management, Vol. 43, No. 1, pp. 56-66. E-ISSN 1873-2062, ISSN 0019-8501. DOI 10.1016/j.indmarman.2013.08.002

[4] Cerchione, R. and Esposito, E. (2017) "Using knowledge management systems: A taxonomy of SME strategies", International Journal of Information Management, Vol. 37, pp. 1551-1562. E-ISSN 1873-4707, ISSN 0268-4012. DOI 10.1016/j.ijinfomgt.2016.10.007.

[5] Chen, F. (2003) "Information Sharing and Supply Chain Coordination", Handbooks in Operations Research and Management Science, Vol. 11, pp. 341-421. E-ISSN 2212-1323, ISSN 0927-0507. DOI 10.1016/S0927-0507(03)11007-9.

[6] Consoli, D. (2012) "Literature analysis on determinant factors and the impact of ICT in SMEs", Procedia - Social and Behavioral Sciences, Vol. 62, pp. 93-97. ISSN 1877-0428. DOI 10.1016/j.sbspro.2012.09.016.

[7] Costantino, F., Di Gravio, G., Shaban, A. and Tronci, M. (2015) “The Impact of Information Sharing on Ordering Policies to Improve Supply Chain Performances", Computer \& Industrial Engineering, Vol. 82, pp. 127-142. E-ISSN 1879-0550, ISSN 0360-8352. DOI 10.1016/j.cie.2015.01.024.

[8] Dabenne, F. and Gay, P. (2011) "Food Traceability Systems: Performance Evaluation and Optimization", Computers and Electronics in Agriculture, Vol. 75, No. 1, pp. 139-146. E-ISSN 1872-7107, ISSN 0168-1699. DOI 10.1016/j.compag.2010.10.009.

[9] Ding, H., Fu, Y., Zheng, L. and Yan, Z. (2019) "Determinants of the Competitive Advantage of Dairy Supply Chains: Evidence from the Chinese Dairy Industry", International Journal of Production Economics, Vol. 209, pp. 360-373. E-ISSN 1873-7579, ISSN 0925-5273. DOI 10.1016/j.ijpe.2018.02.013.

[10] Dominguez, R., Cannella, S., Barbosa-Póvoa, A. P. and Framinan, J. M. (2018) “Information Sharing in Supply Chains with Heterogeneous Retailers", Omega, Vol. 79, pp. 116-132. ISSN 035-0483. DOI 10.1016/j.omega.2017.08.005.

[11] European Commission (2018) "Growth - Internal Market, Industry, Entrepreneurship and SMEs. Smart use of ICT for SMEs". [Online]. Available: https://ec.europa.eu/growth/industry/policy/ digital-transformation/smart-use-ict-smes_en [Accessed: 15 Jan. 2019].

[12] Eurostat. (2008) "NACE Rev. 2 Statistical classification of economic activities in the European Community", Eurostat Methodologies and Working papers, 2008. [Online]. Available: https:// ec.europa.eu/eurostat/documents/3859598/5902521/KS-RA-07-015-EN.PDF [Accessed: 25 Feb. 2019]. ISSN 1977-0375.

[13] FAO (2016) "eFoodChain project. Exploiting the innovative potential of standardized digital data exchanges along the agri-food supply chain" [Online]. Available: http://aims.fao.org/activity/blog/ efoodchain-project-exploiting-innovative-potential-standardized-digital-data-exchanges [Accessed: 12 Mar. 2019].

[14] Fawcett, S. E., Wallin, C., Allred, C., Fawcett, A. M. and Magnan, G. M. (2011) "Information Technology as an Enabler of Supply Chain Collaboration: A Dynamic-Capabilities Perspective", Journal of Supply Chain Management, Vol. 47, No. 1, pp. 38-59. ISSN 1745-493X. DOI 10.1111/j.1745-493X.2010.03213.x. 
[15] Felföldi, J., Botos, Sz., Péntek, Á., Szilágyi, R. and Várallyai, L. (2017) "Studying the ICT management of agri-food sector on supply chain level - the first stage: analysis of agricultural ICT usage", Agricultural Sector Issues in the European Periphery: Productivity, Export and Development Challenges, Wilmington, Vernon Press, pp. 35-50. ISBN 978-1-62273-272-2

[16] Fiala, P. (2005) "Information sharing in supply chains", Omega, Vol. 33, pp. 419-423. E-ISSN 1873-5274, ISSN 0305-0483. DOI 10.1016/j.omega.2004.07.006.

[17] Füzesi, I., Lengyel, P., Csobán, K. and Szilágyi, R. (2016a) “Analysis of ICT Support in Hungarian Meat Sector”, Agrárinformatika / Journal of Agricultural Informatics, Vol. 7, No 2, pp. 60-69. ISSN 2061-862X. DOI 10.17700/jai.2016.7.2.306.

[18] Füzesi, I., Lengyel, P., Szilágyi, R. and Ráthonyi, G. (2016b) “Application of EDI Technologies in the Food Supply Chains", Journal of EcoAgriTourism, Vol. 121, No. 32, pp. 69-77. ISSN 1844-8577.

[19] Giotopoulos, I., Kontolaimou, A., Korra, E. and Tsakanikas, A. (2017) "What drives ICT adoption by SMEs? Evidence from a large-scale survey in Greece", Journal of Business Research, Vol. 81, pp. 60-69. E-ISSN 1873-7978, ISSN 0148-2963. DOI 10.1016/j.jbusres.2017.08.007.

[20] Grimm, J. H., Hofstetter, J. S. and Sarkis, J. (2014) “Critical Factors for Sub-Supplier Management: A Sustainable Food Supply Chains Perspective", International Journal of Production Economics, Vol. 152, pp. 159-173. E-ISSN 1873-7579, ISSN 0925-5273. DOI 10.1016/j.ijpe.2013.12.011.

[21] Gupta, P., Seetharaman, A. and Raj, J. R. (2013) "The usage and adoption of cloud computing by small and medium businesses", International Journal of Information Management, Vol. 33, pp. 861-874. E-ISSN 1873-4707, ISSN 0268-4012. DOI 10.1016/j.ijinfomgt.2013.07.001.

[22] Hassan, H. (2017) "Organisational factors affecting cloud computing adoption in small and medium enterprises (SMEs) in service sector”, Procedia Computer Science, Vol. 121, pp. 976-981. ISSN 1877-0509. DOI 10.1016/j.procs.2017.11.126.

[23] Hungarian Central Statistical Organisation (HCSO). [Online]. Available: http://www.ksh.hu. [Accessed: 20 Jan. 2019].

[24] Kirilova, E. G. and Vaklieva-Bancheva, N. G. (2017) "Environmentally Friendly Management of Dairy Supply Chain for Designing a Green Products' Portfolio", Journal of Cleaner Production, Vol. 167, pp. 493-504. ISSN 0959-6526. E-ISSN 1879-1786. DOI 10.1016/j.jclepro.2017.08.188.

[25] Kubicová, L., Predanocyová, K. and Kádeková, Z. (2019) "Factors Affecting the Demand for Milk and Dairy Products in the Slovak Republic", Agris on-line Papers in Economics and Informatics, Vol. 11, No. 4, pp. 39-47. ISSN 1804-1930. DOI 10.7160/aol.2019.110404.

[26] Látečková, A., Bolek, V. and Szabo, L. (2018) "Information Systems in Agricultural Enterprises: An Empirical Study in Slovak Republic", Agris on-line Papers in Economics and Informatics, Vol. 10, No. 2, pp. 49-60. ISSN 1804-1930. DOI 10.7160/aol.2018.100205.

[27] Maloni, M. J. and Brown, M. E. (2006) "Corporate Social Responsibility in the Supply Chain: An Application in the Food Industry", Journal of Business Ethics, Vol. 68, No. 1, pp. 35-52. ISSN 1573-0697. DOI 10.1007/s10551-006-9038-0.

[28] Masner, J., Jarolímek, J. and Kánská, E. (2018) "Novel Approach for Creation, Storage and Presentation of Online Information Content", Agris on-line Papers in Economics and Informatics, Vol. 10, No. 3, pp. 69-77. ISSN 1804-1930. DOI 10.7160/aol.2018.100306.

[29] Modimogale, L., Jan, H. and Kroeze, J. H. (2011) "The Role of ICT within Small and Medium Enterprises in Gauteng", Communications of the IBIMA, IBIMA Publishing, Vol. 2011, 12 p. ISSN 1943-7765. DOI 10.5171/2011.369288.

[30] Norman, G. (2010) "Likert Scales, Levels of Measurement and The "Laws" of Statistics", Advances in Health Sciences Education, Vol. 15, No. 5, pp. 625-632. ISSN 1573-1677. DOI 10.1007/s10459-010-9222-y. 
[31] Pant, R. R., Prakash, G. and Farooquie, J. A. (2015) "A Framework for Traceability and Transparency in the Dairy Supply Chain Networks", Procedia - Social and Behavioral Sciences, Vol. 189, pp. 385-394. ISSN 1877-0428. DOI 10.1016/j.sbspro.2015.03.235.

[32] Plumb, I. and Zamfir, A. (2008) "Use of ICT in SMEs management within the sector of services", Annals of the University of Oradea, Economic Science Series, Vol. 17, No. 4, pp. 481-487. ISSN 1582-5450.

[33] Sultan, N. A. (2011) "Reaching for the "cloud": How SMEs can manage", International Journal of Information Management, Vol. 31, pp. 272-278. E-ISSN 1873-4707, ISSN 0268-4012. DOI 10.1016/j.ijinfomgt.2010.08.001.

[34] Taruté, A. and Gatautis, R. (2014) "ICT impact on SMEs performance", Procedia - Social and Behavorial Sciences, Vol. 110, pp. 1218-1225. ISSN 1877-0428. DOI 10.1016/j.sbspro.2013.12.968.

[35] Teunter, R. H., Babai, M. Z., Bokhorst, J. A. C. and Syntetos, A. A. (2018) "Revisiting the Value of Information Sharing in Two-Stage Supply Chains", European Journal of Operational Research, Vol. 270, pp. 1044-1052. E-ISSN 1872-6860, ISSN 0377-2217. DOI 10.1016/j.ejor.2018.04.040.

[36] Trienekens, J. H., Wognum, P. M., Beulens, A. J. and van der Vorst, J. G. (2012) “Transparency in Complex Dynamic Food Supply Chains", Advanced Engineering Informatics, Vol. 26, No. 1, pp. 55-65. E-ISSN 1873-5320, ISSN 1474-0346. DOI 10.1016/j.aei.2011.07.007.

[37] Tutunea, M. F. (2014) "SMEs' perception on cloud computing solutions", Procedia Economics and Finance, Vol. 15, pp. 514-521. ISSN 2212-5671. DOI 10.1016/S2212-5671(14)00498-5.

[38] Vasiljeva, T., Shaikhulina, S. and Kreslins, K. (2017) "Cloud Computing: Business Perspectives, Benefits and Challenges for Small and Medium Enterprises (Case of Latvia)", Procedia Engineering, Vol. 178, pp. 443-451. ISSN 1877-7058. DOI 10.1016/j.proeng.2017.01.087.

[39] Veveris, A., Šapolaite, A., Raišienè, A. G. and Bilan, Y. (2019) "How Rural Development Programmes Serve for Viability of Small farms? Case of Latvia and Lithuania", Agris on-line Papers in Economics and Informatics, Vol. 11, No. 2, pp. 103-113. ISSN 1804-1930. DOI 10.7160/aol.2019.110210.

[40] Viet, N. Q., Behdani, B. and Bloemhof, J. (2018) "The Value of Information in Supply Chain Decisions: A Review of the Literature and Research Agenda", Computers \& Industrial Engineering, Vol. 120, pp. 68-82. E-ISSN 1879-0550, ISSN 0360-8352. DOI 10.1016/j.cie.2018.04.034.

[41] Wu, Z. and Jia, F. (2018) “Toward a Theory of Supply Chain Fields - Understanding the Institutional Process of Supply Chain Localization”, Journal of Operations Management, Vol. 58-59, pp. 27-41. E-ISSN 1873-1317, ISSN 0272-6963. DOI 10.1016/j.jom.2018.03.002.

[42] Yunis, M., Tarhini, A. and Kassar, A. (2018) "The role of ICT and innovation in enhancing organizational performance: The catalysing effect of corporate entrepreneurship", Journal of Business Research, Vol. 88, pp. 344-356. E-ISSN 1873-7978. ISSN 0148-2963. DOI 10.1016/j.jbusres.2017.12.030.

[43] Zhou, H., Shou, Y., Zhai, X., Li, L., Wood, C. and Wu, X. (2014) "Supply Chain Practice and Information Quality: A Supply Chain Strategy Study", International Journal of Production Economics, Vol. 147, pp. 624-633. E-ISSN 1873-7579, ISSN 0925-5273. DOI 10.1016/j.ijpe.2013.08.025. 